\title{
Ethical Decision Making: A Role-Play Exercise
}

\author{
Ankur Nandedkar ${ }^{1} \&$ David J. DiRusso ${ }^{1}$ \\ ${ }^{1}$ Department of Management \& Marketing, Millersville University of Pennsylvania, Millersville, PA, USA \\ Correspondence: Ankur Nandedkar, Department of Management \& Marketing, Millersville University of \\ Pennsylvania, Millersville, PA 17551, USA. E-mail: Ankur.Nandedkar@Millersville.edu
}

Received: March 23, 2019

Accepted: April 20, 2019

Online Published: June 23, 2019

doi:10.5539/ijbm.v14n7p185

URL: https://doi.org/10.5539/ijbm.v14n7p185

\begin{abstract}
This paper highlights an original role-play exercise designed to teach students about the principles of ethical decision making. The exercise intends to create hypothetical ethical dilemmas that managers may encounter in their jobs, and challenges the students to apply the principles of ethical decision making to reach a solution in each case. This exercise is ideal for use by instructors of introductory courses such as principles of management, introduction to business or graduate level business administration concepts, or any class session with a primary focus on ethical decision making. We present a description of the exercise and suggestions on how to debrief it. The exercise also provides students with an opportunity to ponder their ethical values and complexities associated with the manager's position in a company.
\end{abstract}

Keywords: role-play, ethics, decision making, exercise

\section{Introduction}

Ethics is one the most pressing issues in the society today. There have been many controversies recently in the corporate sectors such as: insider trading at Equifax, wrongdoings by Volkswagen, Bill O'Reilly scandal at Fox News, and Apple's questionable action of slowing down older iPhones (Shen, 2017). These fiascos have reemphasized the needs to instill ethical decision making in managers. As management educators, we are responsible for creating the leaders of tomorrow, but executing a class session that can spark excitement within students about ethics is a pedagogical challenge. Therefore, selecting an appropriate technique is instrumental to make an impact on students.

Lectures are common in business schools (Farashahi \& Tajeddin, 2018) and perceived as a systematic method that emphasizes on the central role of the teacher to familiarize the learner with the external world (Ardalan, 2006). Teaching through lectures is pertinent for providing a substantial number of ideas, theories, and principles to a large number of students (Cadotte, 1995). Learners experience a constrained environment during lectures to develop their managerial skills and understand the application of their knowledge to the real-world (Farashahi \& Tajeddin, 2018). In addition, the opportunities to promote creative and innovate learning are limited during lectures (Heremens \& Clarke, 2009); however, lectures are critical when objective is to deliver the basic content (Bedwell, Fiore, \& Salas, 2014) and provide more control to the instructor. Lectures are also regarded as less intimidating by the introverted learners (Griffin \& Cashin, 1989), and offer declarative knowledge that is required for developing skills and implementing them in the real world (Salas, Wildman, \& Piccolo, 2009). Thus, lectures can shape the foundation for active learning rather than being an active learning pedagogy. Felder \& Brent (2009) define active learning as "anything course-related that all students in a class session are called upon to do other than simply watching, listening and taking notes" (p. 2). Research has demonstrated that small group discussion, short written exercises, think-pair-share activities, debates, role-playing, and polling are all part of active learning pedagogies that faculty members use in the classroom (Bonwell \& Eison, 1991; Cadotte, 1995). The core elements of active learning are student activity and engagement in the learning process.

Although instructors make considerable effort in preparing for class lectures that are informative by maintaining currency in the field, sharing personal experiences, focusing on recent corporate events, and utilizing other strategies to make the course material relevant and interesting, the students remain passive during the session. Since ethical decision making is inherently an active process, students should benefit from an educational technique that can harness the strengths of lecture coupled with immersive experience of active learning. Baker and Comer (2009) have asserted that educators should strive to provide students with the opportunities that can 
help them learn how to deal with ethical situations in the real-world. The focus should not only be on developing a solution but also understanding the implications for all the stakeholders involved. To this end, the paper highlights a role-play exercise to actively involve students in the decision-making process by using principles of ethical decision making. In the following sections, the learning objectives of the exercise are discussed, followed by a description of the requirements of the exercise and stepwise instructions for classroom facilitation. The final section outlines potential questions and answers to be discussed after completion of the exercise.

\section{Method}

The following subsections will highlight various details of the exercise:

\subsection{Learning Objectives}

After completing this exercise, students should be able to:

- Identity the principles of ethical decision making

- Recognize challenges associated with ethical decision making

- Apply ethical decision making principles to solve a dilemma

\subsection{Target Audience}

This exercise has been successfully used in undergraduate Principles of Management and graduate Business Administration Concepts class. It can also be used in any class when the topic of ethical decision making is discussed. This exercise is best suited for a 75-minute class (refer to Table 1) but can be adjusted for a shorter (50-minute) class session.

\subsection{Materials Needed}

Appendices A, B, C, D, E, F, \& G

Appendices A \& B describe the managerial situations, therefore, some students playing the role of managers should be handed appendix A while other should receive B, but both groups of managers should be given a copy of ethical decision making principles outlined in the appendix C. The four teams enacting the ethical dilemmas should be given remaining appendices such that each team gets only one appendix. The appendix received by a team becomes the dilemma that the team will have to enact for the managers.

\subsection{Writing Tools}

The instructor will need dry-erase markers to highlight important concepts on the whiteboard during the discussion and debrief session.

\subsection{Advance Preparation by the Instructors}

Before administering this exercise, instructors should:

- Prepare for a mini-lecture based on seven principles of ethical decision making

- Read through the entire exercise

- Depending on the class size, plan for the number of students that will be given the role of managers for the exercise. The size of each team enacting ethical dilemma will be three members, but the number of managers can vary. Typically for a class size of twenty-five, twelve students can be assigned to enact the scenes as a part of team, while others can play managers.

\subsection{Advance Preparation by Students}

The students don't require any advance preparation for participation in the exercise for the 75- minute class period. Once the instructor provides documents, they would need to read the handout of the situation given to them and plan about enacting the scene, but for the 50-minute class meeting, advance preparation will be required as outlined in Table 2.

\subsection{Conducting the Exercise}

- Instructor will describe the purpose of the exercise to class

○ Instructor then asks for volunteers to play the role of managers; the suggested number of managers is 4 , but it can be done with fewer or more students playing managers depending on the class size.

$\circ \quad$ Each manager meets the four teams with one team at a time. 
- The teams will enact the assigned scene for mangers that will put them in a challenging situation; the managers are expected to solve the problem by applying principles of ethical decision making and write the solution on a piece of paper with their justification.

- After the role-plays are done, instructor will facilitate the class discussion related to the decision each manager made and the underlying rationale based on the principles of ethical decision making.

The following table outlines the details of each step and approximate time frame for the 75-minute class session:

\begin{tabular}{|c|c|c|}
\hline Step & Description & $\begin{array}{l}\text { Time } \\
\text { frame }\end{array}$ \\
\hline Mini-lecture & Instructor explains the principles of ethical decision making and provides relevant examples & $\begin{array}{l}10 \\
\text { minutes }\end{array}$ \\
\hline Introduction & $\begin{array}{l}\text { Instructor introduces the role-play exercise; selects } 4 \text { teams of three students each to enact ethical dilemmas, } \\
\text { and assigns the role of managers to the rest of the students }\end{array}$ & $\begin{array}{l}7 \\
\text { minutes }\end{array}$ \\
\hline $\begin{array}{l}\text { Hand-out } \\
\text { Distribution }\end{array}$ & $\begin{array}{l}\text { Appendices A \& B contain managerial situation, so it is given to students playing the role of manager as } \\
\text { explained earlier. The appendix C highlights ethical decision making principles is handed over to each } \\
\text { student. The teams should be given the appendix corresponding to the ethical dilemma they are assigned to } \\
\text { enact. }\end{array}$ & $\begin{array}{l}3 \\
\text { minutes }\end{array}$ \\
\hline Preparation & $\begin{array}{l}\text { The student teams read their dilemma and prepare to enact the scene while students playing managers read } \\
\text { the situation assigned to them and review principles of ethical decision making appendix. The instructor } \\
\text { then responds to any follow-up questions students may have. }\end{array}$ & $\begin{array}{l}5 \\
\text { minutes }\end{array}$ \\
\hline Role-play & $\begin{array}{l}\text { Each manager meets with all the four teams. The teams present the ethical dilemma scene in about } 3 \\
\text { minutes and managers have additional } 3 \text { minutes to make their decision and write the rationale. }\end{array}$ & $\begin{array}{l}25 \\
\text { minutes }\end{array}$ \\
\hline Debrief & $\begin{array}{l}\text { The instructor facilitates class discussion based on the input from students who played managers in the } \\
\text { exercise. }\end{array}$ & $\begin{array}{l}25 \\
\text { minutes }\end{array}$ \\
\hline
\end{tabular}

As described earlier, this exercise can also be used for a shorter class length of 50 minutes. The following table represents minor modifications to the original exercise to make it suitable for the 50-minute period.

\begin{tabular}{|c|c|c|}
\hline Step & Description & Time frame \\
\hline Mini-lecture & $\begin{array}{l}\text { The instructor explains the principles of ethical decision making and provides } \\
\text { relevant examples }\end{array}$ & 10 minutes \\
\hline Introduction & $\begin{array}{l}\text { The instructor introduces the role-play exercise; selects } 4 \text { teams of three students each } \\
\text { to enact ethical dilemmas, and assigns the role of managers to the rest of the students }\end{array}$ & $\begin{array}{l}\text { (Team division and manager } \\
\text { role allocation is done in the } \\
\text { prior class meeting) }\end{array}$ \\
\hline $\begin{array}{l}\text { Hand-out } \\
\text { Distribution }\end{array}$ & $\begin{array}{l}\text { The appendices A \& B contain managerial situation, so it is given to students playing } \\
\text { the role of manager as explained earlier. The appendix C highlights ethical } \\
\text { decision-making principles is handed over to each student. The teams should be } \\
\text { given the appendix corresponding to the ethical dilemma they are assigned to enact. }\end{array}$ & $\begin{array}{l}\text { (Handout with details } \\
\text { regarding roles are given in } \\
\text { advance to students so they can } \\
\text { prepare before class meeting) }\end{array}$ \\
\hline $\begin{array}{l}\text { Follow-up } \\
\text { questions }\end{array}$ & $\begin{array}{l}\text { Students know their roles and have prepared in advance. The instructor answers any } \\
\text { questions that students may have before the exercise. }\end{array}$ & 3 minutes \\
\hline Role-play & $\begin{array}{l}\text { The instructor assigns each manager to meet with two teams. The teams execute the } \\
\text { scene in about } 3 \text { minutes and managers have another } 3 \text { minutes to make their decision } \\
\text { and provide rationale. }\end{array}$ & 12 minutes \\
\hline Debrief & $\begin{array}{l}\text { The instructor facilitates class discussion based on the input from students who } \\
\text { played managers in the exercise. }\end{array}$ & 25 minutes \\
\hline
\end{tabular}

\section{Discussion}

We found that students enjoy the role-play primarily for two reasons. First, an opportunity to act; second, the simulated environment to experience complexities associated with ethical dilemmas in an organizational context. The following questions can be used for post-activity discussion:

1. What is the correct solution for each problem? For example, should you grant full retirement benefits in ethical dilemma \# 1 ? 
Students often are confused when the word 'correct' is used in the question. They respond that there is no correct answer in each case, which is certainly the appropriate way to respond to this question. While it may be possible to argue that a correct solution exists if one ethical principle is used for the exercise, but this activity requires students to critically analyze and apply from multiple ethical decision making principles, so it is difficult to support one solution as being correct. Therefore, the word 'correct' should be intentionally used in the question to emphasize the point that there is no 'correct' or 'incorrect' answer in such situation.

Usually, dilemma \# 1 and dilemma \#4 leads to much debate and discussion. For dilemma \# 1, many students have a sympathetic point of view and respond they would give the full benefits to the family of the deceased employee by applying the principles of distributive justice and religious injunctions, while others argue they would deny the benefits citing the principle of long-term self-interest and personal virtue. They further emphasize that main issue is about strictly following company policies; if the manager makes an exception in this case, then an exception should be made for future incidences, which would eventually affect company's revenue and send a message that policies are not enforced.

For dilemma \# 4, some students use principle of utilitarian benefits and long-term self-interest to argue they would approve the deal because it brings the company back to profits and would eventually save the layoffs, but others use personal virtue and religious injunctions and justify that client deserves to receive the market value for the properties.

2. What factors should be considered while ethical decision making?

Student responses to this question vary widely. Some of the answers include what other people in the firm feel about the situation, whether decision maker personally knows the person that will be affected by the decision, past experiences of the manager in such situations, relationships with other employees, and consequences of the decision on one-self or the company etc.

\section{How does the centralized/decentralized structure of the company affect the managerial decision making?}

Students typically respond the structure of the company will affect the way manager deals with difficult situations. For example, if a company follows centralized (top-down) decision making; even though, within their power, some managers would want to consult the upper echelon before making the decision. They just want to be sure they don't make a decision which might be criticized by the top management. On other hand, decentralized structure lends more of free hand in decision making since the culture is overall supportive and encourages autonomy.

4. Do you think the presence of unionized environment affects managerial decision making?

Many students aren't much aware of the concept of labor unions, so it also serves as a good opportunity for them to learn about the benefits of working in unionized environments such as: higher job security, employee voice, better wages and benefits. Student that have prior knowledge about unions typically respond in an affirmative way. Their rationale is managers would make decisions that favor employees, because management strives to maintain good working relationships to avoid strikes.

5. What are the takeaways from the exercise?

Student responses to the question vary but typically include absence of a right or wrong solutions for each situation. It is arguably the most important point in ethical decision making topic. Other points to be emphasized are to learn about complexities associated with a manager's job such as correctly interpreting the situation, understanding stakeholder perceptions, contemplating about short-term and long-term consequences of the decision on the parties involved, and finally being confident to defend the decisions made.

\section{Conclusion}

This exercise was developed to create an engaging experience for students while they learn about ethical decision making. It can be used in courses such as principles of management, principles of marketing, business administration concepts, or any other class in which the topic of ethical decision making is introduced. This exercise provides students with an opportunity to apply ethical decision making principles in a simulated workplace environment. It is our hope that by using this exercise, instructors can bring an otherwise abstract topic to life; increase student interest; and create a memorable class session.

\section{References}

Ardalan, K. (2006). The philosophical foundation of the lecture-versus-case controversy: Its implications for faculty teaching, research, and service. International Journal of Social Economics, 33(3), 261-281. 
Baker, S. D., \& Comer, D. R. (2012). "Business Ethics Everywhere” An Experiential Exercise to Develop Students' Ability to Identify and Respond to Ethical Issues in Business. Journal of Management Education, $36(1), 95-125$.

Bedwell, W. L., Fiore, S. M., \& Salas, E. (2014). Developing the future workforce: An approach for integrating interpersonal skills into the MBA classroom. Academy of Management Learning \& Education, 13(2), 171-186.

Bonwell, C. C., \& Eison, J. A. (1991). Active Learning: Creating Excitement in the Classroom. 1991 ASHE-ERIC Higher Education Reports. ERIC Clearinghouse on Higher Education, The George Washington University, One Dupont Circle, Suite 630, Washington, DC 20036-1183.

Cadotte, E. R. (1995). Business simulations: The next step in management training. Selections, 54(2), 8-16.

Farashahi, M., \& Tajeddin, M. (2018). Effectiveness of teaching methods in business education: A comparison study on the learning outcomes of lectures, case studies and simulations. The International Journal of Management Education, 16(1), 131-142.

Felder, R. M., \& Brent, R. (2009). Active learning: An introduction. ASQ higher education brief, 2(4), 1-5.

Griffin, R. W., \& Cashin, W. E. (1989). The lecture and discussion method for management education: Pros and cons. Journal of Management Development, 8(2), 25-32.

Hermens, A., \& Clarke, E. (2009). Integrating blended teaching and learning to enhance graduate attributes. Education+ Training, 51(5/6), 476-490.

Salas, E., Wildman, J. L., \& Piccolo, R. F. (2009). Using simulation-based training to enhance management education. Academy of Management Learning \& Education, 8(4), 559-573.

Shen, Lucinda. (2017, December, 31). The 10 Biggest Business Scandals of 2017. Retrieved from http://fortune.com/2017/12/31/biggest-corporate-scandals-misconduct-2017-pr/

Williams, C. (2015). Management. Mason, OH: South-Western Cengage Learning.

\section{Appendix A}

Manager 1

Your company has a centralized structure. The upper echelon implements most of the decisions and middle or lower level management do not have much autonomy. There is no labor union, so the bargaining power of employees for most of the decisions that affect them is comparatively weaker.

\section{Appendix B}

Manager 2

Your company has a decentralized structure. The top management has given middle managers and lower level managers autonomy to handle various situations that occur in their jobs. In addition, there is a union, which gives employees strong bargaining power in the decisions that affect them.

\section{Appendix C}

Principles of Ethical Decision Making

Principle of long-term self-interest: You should never take any action that is not in your or your organization's long-term self-interest.

Principle of personal virtue: You should never do anything that is not honest, open, and truthful.

Principle of religious injunctions: You should never take any action that is unkind or that harms a sense of community such as the positive feelings that come from working together to accomplish a commonly accepted goal.

Principle of government requirements: The law represents minimal moral standards of the society, so you should never take any action that violates the law.

Principle of utilitarian benefits: You should never take an action that doesn't result in greater good for society.

Principle of distributive justice: You should never take any action that harms the least fortunate among us in some way.

Principle of individual rights: You should never take an action that infringes on other's agreed-upon rights. 
Principles of Ethical Decision Making adopted from Chuck Williams (2015).

\section{Appendix D}

\section{Ethical Dilemma \# 1}

Narrator: This scene is related to the death of a senior employee in the firm. The employee worked for the firm for over 29 years and was one of the star performers. Unfortunately, sudden heart attack killed the employee while on the way to work. The employee had no serious health problems and the untimely demise has stunned the family. There were about 15 days remaining for the employee to complete 30 years of service. Employee's immediate family consists of a spouse, 47 , and a child aged 19 years. The spouse is disabled, and receives some support from the government. The child is an ambitious individual, recently finished high school, and is excited to go college to fulfill the long-standing dream of becoming a medical doctor. Employee's income was the major funding source for the family. The company has a policy of providing retirement benefits to employees who have completed at least 30 years of service. Full retirement benefits would give the employee's family about $\$ 2000$ in monthly pension, and a provision of $\$ 100$ in monthly health insurance premiums to cover the family, while partial retirement benefits will include $\$ 600$ in pension and $\$ 350$ for insurance premium.

The family of the late employee is at the office to meet the benefits coordinator (BC).

Spouse: Good Morning!

BC: Good morning! Please have seat; how may I help you?

Spouse: We are here to discuss an important issue. The family was dependent on my spouse's income, and after the tragic death, we hardly have any source of income.

BC: It's very sad news. The employee was one of the best we had.

Child: I plan to go college full time to complete my pre-med as I want to eventually get into medical school. I cannot work because the school has a policy of admitting full-time students that don't work elsewhere in any capacity.

Spouse: As you may know, only 15 days were remaining for my spouse to complete the required 30 years of service time to become eligible for full retirement benefits, and it will be very unfortunate for us to receive partial benefits given my spouse's contribution to the firm for last several years.

Child: Because there was such a short time left for eligibility, can you please consider granting the full-retirement benefits to us? At this juncture, it would be extremely helpful.

BC: I understand your situation, but is outside of my authority to make this decision. I will speak with my manager about it, and you will receive a letter from the company in the mail over the next few days describing the outcome.

Narrator: As a manager in this company, you have to decide whether to grant the full retirement benefits to the family.

\section{Appendix E}

\section{Ethical Dilemma \# 2}

Narrator: This scenario is about a company that makes customer relationship management software for midsize businesses. It has about 700 employees across three locations in the U.S. The company's profit grew exponentially in the last few years, but many employees have complaints that there is neither a profit sharing culture in the company nor they have received the raise in the last few years. Employees, A and B, are two software engineers that have worked for the company for the last seven years. A is known for strong software development skills, and helping attitude towards colleagues regarding work related issues. A and B together work on the same team and recently have developed a game for the android platform that they think can make it big.

A: I think this game can make it even bigger than Pokémon Go.

B: I agree and the credit goes to you. You have tremendous passion for software development.

A: I don't want to take the complete credit because on several occasions during the process, you have given a valuable input, which worked out well. As such, without your help it wasn't possible.

\section{B: Thanks!}

A: I believe that our president will be very happy, if this game is a success. 
B: I don't feel that we must inform anyone about this game. This is a product of our hard work and we have developed it in the spare time we had after completing the last three projects much before the deadline. We can market this product on our own and make big bucks!!

A: I disagree with you because we have used company's resources in building this software.

B: Not an issue. I have a suggestion: let's inform our project manager and we will let manager make the decision. We all went to college together and share a strong bond, so I'm sure the discussion will remain confidential.

Narrator: Being their manager, you must decide in this situation whether to inform the president regarding this new software or kept it as a secret shared by three friends. How would you handle it?

\section{Appendix F}

Ethical dilemma \# 3

Narrator: This scene is about an article a journalist is trying to publish in the local newspaper. The article covers an ethnic restaurant, Zwala's Kitchen. It is the best restaurant in town and does a roaring business. Majority of the sales revenue is based on five dishes mainly made from red meat. The dishes are unique and aren't available in any of the other nearby restaurants. These delicacies are extremely popular among residents and they often recommend friends and family to try it; people from nearby cities have also frequently visited.

The newspaper has a strong reputation for providing credible stories with no bias to the residents for the last several years. The editor of the newspaper and the owner of Zwala's Kitchen have been good friends for many years. The newspaper recently hired a journalist and this journalist is discussing a potential article for publication in the newspaper with a colleague.

Journalist: Hey! I'm working on this news article that I am planning to send it to the editor.

Colleague: What is it about?

Journalist: It is about five research studies that have been recently published in three top tier medicine journals, and provide an evidence of a strong link between eating red meat and colon cancer in humans.

Colleague: I don't think, you should even talk about this story to the boss.

Journalist: Why?

Colleague: If this news article gets published, it may have a negative impact on the business of Zwala's Kitchen.

Journalist: Why should we be concerned for their sales?

Colleague: Our editor and restaurant owner are good friends, and restaurant has a yearly advertisement account with us which is worth $\$ 50,000$; so the editor will never approve of such news article.

Journalist: As a newspaper known for its credibility, it is our mission and moral duty to inform people about the truth and let them decide. I think the editor should not have any qualms about running this news story.

Colleague: If you think so, let's go ahead and talk to the editor.

Journalist: Okay.

Narrator: As the managing editor, you must make a decision whether to publish the news article.

\section{Appendix G}

Ethical Dilemma \# 4

Narrator: This scene is about a real estate firm known as Kumins Inc. The firm had tremendous business earlier, but things have changed in the past three years. There have been new competitors in the city using innovate business models and providing great customer service. As a result, business of Kumins is on decline. The firm made losses for the last two years and is considering laying off some of its employees to reduce the expenses. The manager has informed employees that if things don't change in the next few months, layoffs are inevitable. Two realtors are discussing about a potential deal that can bring back profit the firm desperately needs.

Realtor 1: I have been talking to Mrs. Rogers for the last two weeks and she wants to sell three of her properties.

Realtor 2: With these new firms offering lucrative deals, I'm glad that some people are still considering business with us.

Realtor 1: Yes, she wants to give us the business because her late husband was friends with our boss. 
Realtor 2: Oh I see.

Realtor 1: Unfortunately, she is suffering from Alzheimer's which has affected her cognitive abilities. She has no heirs, so she wants to sell the properties, give majority of the money to charity and move to Florida at a senior care for the rest of her life.

Realtor 2: Have you visited the properties?

Realtor 1: I toured the properties last week and present market value is approximately $\$ 1$ million in total; however, she has no idea about the current value and thinks it would be best if she can sell it off for half a million. She is in a hurry!

Realtor 2: Wow!

Realtor 1: I think if our firm can buy it, and later sell it off at the market price; it would be a quick profit.

Realtor 2: I don't think it's a good idea; it is our moral duty to inform her about the current market value and she should receive the current market value.

Realtor 1: Don't be silly; she is very rich, and it won't affect her because she has plans to give the money to charity anyway. If our company can make a profit, it might save some jobs.

Realtor 2: Dude, it is a very difficult situation. I think we should inform our manager.

Realtor 1: OK.

Narrator: As a manager, how would you handle this situation?

\section{Copyrights}

Copyright for this article is retained by the author(s), with first publication rights granted to the journal.

This is an open-access article distributed under the terms and conditions of the Creative Commons Attribution license (http://creativecommons.org/licenses/by/4.0/). 